\title{
PREVALENCE OF HYPERURICEMIA AMONG PEOPLE OF MORANG DISTRICT OF NEPAL
}

\author{
Shrawan Kumar yadav, Niraj Nepal and DilliRam Niroula.
}

\begin{abstract}
Hyperuricemia refers to an elevation in the serum uric acid concentration. The blood levels of uric acid are a function of the balance between the breakdown of purines $\&$ the rate of uric acid excretion. Theoretically, alterations in this balance many account for hyperuricemia. Prolonged hyperuricemia often associated with gout, is an important risk factor for damaged joints. The present study is undertaken with the aim to find out the prevalence of hyperuricemia by age $\&$ sex, to establish the statistically significant correlation between serum creatinine \& triglyceride concentration with uric acid concentration \& to study the relation between alcohol drinking \& hyperuricemia in Morang District, by routine health examinations in the out Patients Department (OPD) of Nobel Medical College, Biratnagar from January 2012 to January 2013. The study reveals that $28.57 \%$ (male $-30.06 \%$, female $-26.61 \%$ ) of patients have been suffering from hyperuricemia. It indirectly indicates hyperuricemia is very frequent in developing country like Nepal. The present study denoted that hyperuricemia is directly related to alcohol consumption in both male \& female.
\end{abstract}

Key words: Hyperuricemia, Gout

\section{Introduction}

Hippocrates, in the fifth century B.C, recognized the distinctive clinical features of gouty arthrilitis, which he inscribed in the oldest recorded medical text ${ }^{1}$. The term gout was given by de Vielehardouin in the $13^{\text {th }}$ century. ${ }^{2}$ Uric acid was first isolated from urine by Karl Wilhelem Scheele in $1776^{3}$. In 1907, Emil Fisher established uric acid to be a purine compound. $^{4}$ The British physician Alfred Baring Garrod demonstracted by the murexide test in increased amount of uric acid in the blood of gouty subjects. ${ }^{5} \mathrm{He}$ also recognized asymptomatic hyperuricemia, the cause and effect relationship of urate deposition and gouty inflammation, the implication of impaired renal function in gout, the relation of hyperuricemia to gout and treatment changes in urate levels preceding gouty attacks.
Uric acid is the final product of purine metabolism in human beings. Unlike allantoin, the more soluble end product found in lower animals, uric acid is a poorly soluble, end product of purine metabolism in humans. Humans have higher levels of uric acid because of a deficiency of the hepatic enzyme, uricase, and a lower fractional excretion of uric acid. Approximately, two thirds of total body urate is produced endogenously, while the remaining one third is accounted for by dietary purines. About $70 \%$ of the urate produced daily is excreted by kidneys, while the rest is eliminated by the intestines.

Hyperuricemia refers to an elevation in the serum uric acid concentration. The blood levels of uric acid are a function of the balance between the breakdown of purines and the rate of uric acid excretion. Theoretically, alterations in this balance may account for hyperuricemia, although clinically defective 
elimination accounts for most cases of hyperuricemia.

Prolonged hyperuricemia often associated with gout, is an important risk factor for damaged joints. ${ }^{6}$ Hyperuricemia has been shown to be associated with several components of metabolic syndrome (Mets) and investigators have postulated that increased concentrations of uric acid may be another important component of the syndrome. ${ }^{7}$ In some epidemiologic studies, a close relationship between hyperucicemia and hypertension, insulin resistance and cardiovascular disease risk factors (such as obesity and smoking) has been reported. ${ }^{8-11}$ Hyperuricemia is diagnosed in $5-30 \%$ of the general population, although the prevalence is higher among some ethnic groups (e.g, Japanese) and appears to be increasing worldwide. $^{12}$ Serum uric acid concentrations are known to increase with age and are further increased after menopause in women. ${ }^{13}$ Considering current increses in the incidence and prevalence of obesity and Mets worldwide, as well as emerging evidence documenting associations between hyperuricemia and cardiovascular complications further investigations are required.

Acheson and $\mathrm{Chan}^{14}$ have expressed the situation well by stating. "The associates of a high uric acid are the associates of plenty."

On the other hands, with rapid economic development, possibility of improved nutrition and promotion of successful health, life expectancy has been prolonged and the elderly population has increased this has true in Morang, a district of Nepal also. Among common disorders of elderly, high serum uric acid levels are found to be directly correlated to hypertension, heart disease, diabetes, kidney disease, dietary habits and nutrition.

Traditionallly, they eat foods that are high in purine such as red meat, beans, cabbage, cauliflower, alcohol and so on.

Little information however exists concerning the prevalence and epidemiological charateristics of hyperuricemia in Nepal. Therefore, the present study is to find out the prevalence of hyperuricemia among Nepali community by routine health examinations in the out patients Department (OPD) of Nobel Medical College, Biratnagar.

\section{Material and Methods}

This study was conducted from January 2012 to January 2013 in Nobel Medical College, Biratnagar, Nepal. In course of study, 287 patients wer sent for the investigation of serum uric acid from different. Out Patients Department (OPD) of this Hospital. These patients were selected for the study. History and clinical examination records of selected patients were collected.

Selected patients were called on next morning in order to collect fasting blood samples. Median cubital vein of the forearm was used for venipuncture.

The age, sex, alcohol habit and all the biochemical parameters were recorded in predesigned close end Proformal. Later on all the information was entered in a computer programmed. Mean \& standard deviation was calculated by excel programmed.

The following tests were carried out in the clinical biochemistry laboratory. Al the necessary quality control measures were applied. Measurement of these parameters has been done on Semi-autoanalyzer.

1. Serum uric acid - by uricase/POD method

2. Blood sugar - by GOD - POD method.

3. Serum creatinine - by Jaffe's method

4. Serum triglycerides - by Glycerol -3phosphate - oxidase (GPO).

\section{Results}

The study was carried out at Department of Biochemisty, Nobel Medical College, Biratnagar. The subjects were taken from Out Patients Department (OPD) of this hospital. 
The study was carried out among the patient attending from January 2012 to January 2013. The total no. of case was 287.

Table No. 4.1 Distribution of Patients according to Sex.

\begin{tabular}{|c|c|c|}
\hline Sex & No. of patients & Percentage \\
\hline Male & 163 & $56.79 \%$ \\
\hline Female & 124 & $43.21 \%$ \\
\hline Total & 287 & $100 \%$ \\
\hline
\end{tabular}

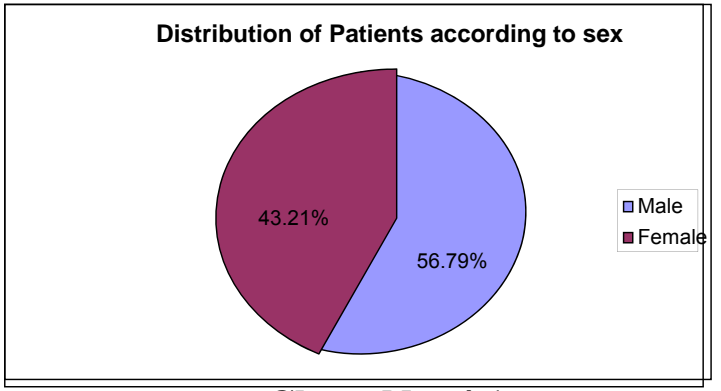

Chart No. 4.1

The majority of the patients in the study were males $(56.79 \%)$ compared to the females $(43.21 \%)$.

Table No. 4.2 Distribution of Patients according to Age

\begin{tabular}{|l|l|l|}
\hline $\begin{array}{l}\text { Age Group } \\
\text { (Years) }\end{array}$ & $\begin{array}{l}\text { No. of } \\
\text { patients }\end{array}$ & Percentage \\
\hline $20-34$ & 96 & $33.45 \%$ \\
\hline $35-49$ & 96 & $33.45 \%$ \\
\hline $50-64$ & 63 & $21.95 \%$ \\
\hline$\geq 65$ & 32 & $11.15 \%$ \\
\hline
\end{tabular}

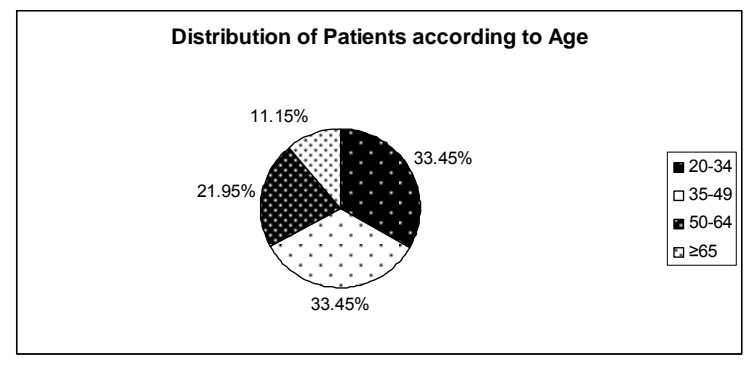

Chart No. 4.2
Above table shows that majority of patients were those who belonged to 20-34 age group and 35-49 (33.45\%). However, 50-64 group was $21.95 \%$ and $\geq 65$ group was $11.15 \%$.

Table No. 4.3 Prevalence of Hyperuricemia by Sex

\begin{tabular}{|l|c|c|c|c|}
\hline Sex & No. & $\begin{array}{l}\text { Avera } \\
\text { ge age } \\
\text { in } \\
\text { Years } \\
\text { Mean } \\
\text { (SD) }\end{array}$ & $\begin{array}{l}\text { Average } \\
\text { Uric acid } \\
\text { (mg/dl) } \\
\text { Mean } \\
\text { (SD) }\end{array}$ & $\begin{array}{l}\text { Prevalenc } \\
\text { of } \\
\text { Hyperurice } \\
\text { mia }\end{array}$ \\
\hline Male & 163 & $\begin{array}{c}43.58 \\
(15.56)\end{array}$ & $\begin{array}{c}6.37 \\
(1.58)\end{array}$ & $30.06 \%$ \\
\hline Femal & 124 & $\begin{array}{c}43.10 \\
(15.75)\end{array}$ & $\begin{array}{c}5.39 \\
(1.53)\end{array}$ & $26.61 \%$ \\
\hline Both & 287 & $\begin{array}{c}43.37 \\
(15.64)\end{array}$ & $\begin{array}{c}5.95 \\
(1.63)\end{array}$ & $28.57 \%$ \\
\hline
\end{tabular}

SD $=$ Standard Deviation

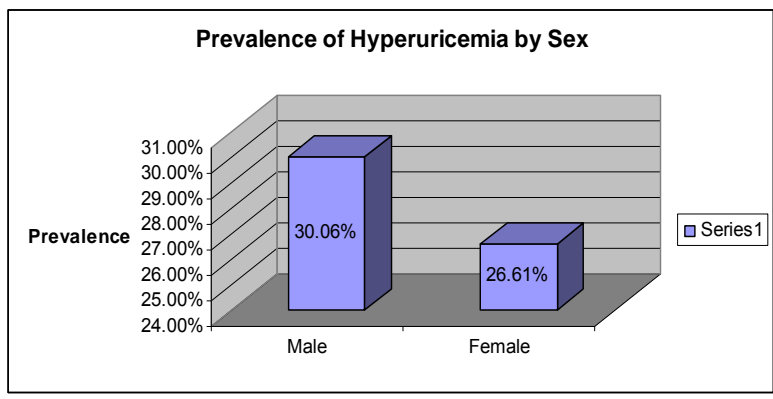

Chart No. 4.3

Above table shows that an average uric acid level in male was $6.67 \pm 1.58$ and for the female was $5.39 \pm 1.53$. The prevalence rate of Hyperuricemia for male was $30.06 \%$ and for the female $26.61 \%$.

Table No. 4.4 Prevalence of Hyperuricemia by Age.

\begin{tabular}{|l|l|l|l|}
\hline Years & No. & $\begin{array}{l}\text { Average } \\
\text { Uric acid } \\
\text { (Mg/dl) } \\
\text { Mean (SD) }\end{array}$ & $\begin{array}{l}\text { Prevalence of } \\
\text { Hyperuricemia }\end{array}$ \\
\hline $20-34$ & 96 & $5.63(1.36)$ & $22.92 \%$ \\
\hline $35-49$ & 96 & $5.73(1.33)$ & $25.00 \%$ \\
\hline $50-64$ & 63 & $5.91(1.43)$ & $28.57 \%$ \\
\hline$\geq 65$ & 32 & $7.61(2.39)$ & $56.25 \%$ \\
\hline
\end{tabular}

SD = Standard Deviation 


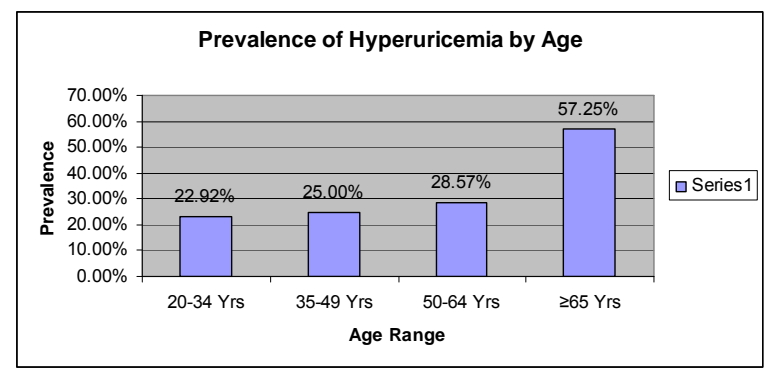

Chart No. 4.4

In above table - highest average uric acid value $(7.61 \pm 2.39)$ was found to be in the age group of $\geq 65$. The prevalence rate of Hyperuricemia was highest in more than $\geq 65$ years group $(56.25 \%)$.

Table No. 4.5 Single Variable Analysis of Hyperuricemia and Measurements

\begin{tabular}{|l|l|l|l|}
\hline $\begin{array}{l}\text { Measuremen } \\
\text { ts }\end{array}$ & $\begin{array}{l}\text { Hyperuri } \\
\text { cemia } \\
\text { (n=82) }\end{array}$ & $\begin{array}{l}\text { Normal } \\
\text { uric acid } \\
\text { (n=205) }\end{array}$ & $\begin{array}{l}\text { P- } \\
\text { valu } \\
\text { e }\end{array}$ \\
\hline $\begin{array}{l}\text { Uric acid } \\
\text { value (mg/d) } \\
\text { Mean (SD) }\end{array}$ & $7.82(1.50)$ & $5.19(0.90$ & $<0.0$ \\
& & ) & 001 \\
\hline $\begin{array}{l}\text { Age(years) } \\
\text { Mean (SD) }\end{array}$ & $48.04(18.1$ & $41.39(14$. & 0.002 \\
\hline $\begin{array}{l}\text { Creatinine(m } \\
\text { g/dl) Mean } \\
\text { (SD) }\end{array}$ & $1.08(0.26)$ & $0.90(0.17$ & $<0.0$ \\
\hline $\begin{array}{l}\text { Fasting } \\
\text { blood sugar } \\
\text { (mg/dl) } \\
\text { Mean(SD) }\end{array}$ & $0)$ & ) & 001 \\
\hline $\begin{array}{l}\text { Triglyceride( } \\
\text { mg/dl) Mean } \\
\text { (SD) }\end{array}$ & $\begin{array}{l}218.20(99 . \\
24)\end{array}$ & $\begin{array}{l}151.98(5 \\
9.60)\end{array}$ & $<0.0$ \\
\hline
\end{tabular}

$\mathrm{NS}=$ no statistical significance

$\mathrm{SD}=$ Standard Deviation

This table showed that hyperuricemia is related to increased age, Creatinine and Triglyceride and it is not related to blood sugar.

Table No. 4.6 Single Variable Analysis of Hyperuricemia and Drinking Alcohol.

\begin{tabular}{|c|c|c|c|c|}
\hline \multirow{2}{*}{$\begin{array}{c}\text { Drinking } \\
\text { Alcohol }\end{array}$} & \multicolumn{2}{|c|}{ Uric acid } & \multirow[t]{2}{*}{$\chi^{2}$} & \multirow{2}{*}{$\begin{array}{c}\text { P- } \\
\text { Value }\end{array}$} \\
\hline & High & Normal & & \\
\hline Yes & 48 & 67 & 16. & 0.000 \\
\hline No & 34 & 138 & 30 & 1 \\
\hline
\end{tabular}

This table showed that hyperuricemia is related to the intake of alcohol.

\section{Discussion}

Serum uric acid has been shown to be related to risk of hypertension, cardiovascular diseases and type 2 diabetes in clinical and epidemiological studies, in addition to gout, which is specific disease caused by high uric acid $^{130-133}$. This study has tried to know the prevalence of hyperuricemia, Morang District and also to know the important risk factors that elevate the serum uric acid levels.

The main observations of the present study are the followings:-

- Firstly the prevalence of the hgyperuricemia was high in Male.

- Secondly, a particularly strong association was found between serum uric acid levels and triglycerides.

- Thirdly, a significant relationship between serum uric acid and creatinine was found.

The present study has revealed that the prevalence of hyperuricemia among the patients, attending Nobel Medical College was $28.33 \%$ (male $30.06 \%$, female $26.61 \%$ ). This value is quite higher than reported for several other populations earlier. The 10.6\% prevalence of hyperuricemia was noted among the men and women, ${ }^{56}$ while Nagahama and colleagues $^{55}$ reported that $24.4 \%$. were diagnosed hyperuricemia in Japan. In Saudi men and women, hyperuricemia is estimated to 8.4\%. ${ }^{58}$ In European countries and United States; hyperuricemia is estimated to 2 to $18 \%$ of the total population ${ }^{134}$.

According to my studies, it was found that serum uric acid levels were higher in men $(6.37 \pm 1.58 \mathrm{mg} / \mathrm{dl})$ than in women $(5.39 \pm 1.53 \mathrm{mg} / \mathrm{dl})$ which is similar to other observations. Studies in Europe and the United states have shown that average uric acid value 
in male is around 5.0 to $5.7 \mathrm{mg} / \mathrm{dl}$ and slightly lower in female at 3.7 to $5.0 \mathrm{mg} / \mathrm{dl}^{135}$.

The prevalence of hyperuricemia is age dependent. In the present study, hyperuricemia was relatively less common among younger subjects (22.92\% in the $20-34$ years age group) but increased considerably to $25 \%$ in the $35-49$ years and $56.25 \%$ was found in $\geq 65$ years age group. Similar patterns of increase prevalence of hyperuricemia with increasing age have been reported by several other investigators. 133,136

In present study serum uric acid concentration was statistically significant and positively correlated with serum triglyceride concentration $(p<0.0001)$ and serum creatinine concentration $(p<0.0001)$. These associations were generally similar to those reported by other investigators. ${ }^{91}, 92,134,135$ The potential mechanisms related hyperuricemia to fasting hypertriglyceridemia are unknown. It has been speculated to be due to an increase in NADPH requirement for de novo fatty acid synthesis in obese men. With increased NADPH, uric acid producton is enhanced, and this might increase serum uric acid level ${ }^{137}$.

My observation showed that alcohol drinking was found to be closely related to hyperuricemia. Alcohol is useful for excretion of uric acid and that the excretion rate of uric acid by the kidney does not decline because of drinking. Alcohol consumption causes accelerated hepatic break down of ATP and increase urate production and also may cause hyperlacticacidemia which competitively blocks the uric acid secretion. ${ }^{121}$ The higher purine content in some alcoholic beverage such as beer may be a factor that increases the uric acid level in blood. ${ }^{122}$

In present study it was not found statically significant relationship between fasting blood sugar and hyperuricemia. Many studies showed similar patterns of finding. ${ }^{138,139}$

Age appeared to be related to hyperuricemia in present study, which was consistent and adjacent with other studies. As the present study showed average age for hyperuricemia was $48.04 \pm 18.18$ with respect to average age of normal uric acid patients 41.39 \pm 14.11 . However, some Asian studies age was reported as risk factors for hyperuricemia in women but in men hyperuricemia was found to decrease with age..$^{57,140}$ This study also emphasized the prevalence of hyperuricemia increased with age (table no. 4.4). Increasing patterns of serum uric acid level with age might be due to impaired renal function, use of diuretics, hypertension as common in elderly patients $^{34,117,118}$.

Although many risks factors that could affect the level of uric acid; unfortunately I did not collect detailed information of other determinations of hyperuricemia.

\section{References}

1. Hippocrates. The Genuine works of Hippocrates, Vols. 1 and 2. Translated from the Greek with a preliminary discourse and annotations by Francis Adams. New York, Wood, 1886.

2. Copeman,. W.S.C: A short History of the Gout, Blerkeley, University of California Press, 1964.

3. Scheele, K.W.: Exameen chemicum calculi urinarii. Opuscual, 2:73,1776.

4. Fischer, E: Unter suchungen in der Puringruppe. Berlin, Springer, 1907.

5. Garrod, A.B: Treatise on Gout and Rheumatic Gout (Rheumatoid Arthritis). $3^{\text {rd }}$ Ed. London, Longmans, Green, 1876.

6. Choi HK, Mount DB, Reginato AM. Pathogenesis of gout. Ann Inntern Med 2005;143:499-516.

7. Bonora E, Targher G, Zenere MB, Saggiani F, Cacciatori V, Tosi F, et al, Relationship of uric acid concentration to cardiovascular risk factors in young men. Role of obesity and central fat distribution. The Verona Young Men Atherosclerosis Risk Factors Study. Int J Obes Relat Metab Disord 1996; 20:975-980.

8. Conen D, Wietlisbach V, Bovet $\mathbf{P}$, Shamlaye C, Riesen W, Paccud F, et al, Prevalence of hyperuricemia and relation of serum uric acid with cardiovascular risk factors in a developing country, BMC Public Health 2004; 25:4-9. 
9. Jossa F, Farinaro F, Panico S, Krogh V, Celentano E, Galasso R, et al. serum uric acid and hypertension; the Oliveti heart study. J Hum Hypertens 1994; 8:677-681.

10. Taniguchi Y, Hayashi T, Tsumura K, Endo G, Fujii S, Okada K. serum uric acid and the risk for hypertension and Type 2 diabetes in Japanes men:
The Osaka Health Survey. J Hypertens 2001: 19:1209-1215.

11. Selby JV, Friedman GD, Queensberry CP Jr. Precursors of essential hypertension; Pulmonary function, heart rate, uric acid, serum cholesterol and other serum chemistries. Am J Epidemiol 1990: 131:101-1027.

Correspondence Address: Mr. Shrawan Kumar yadav, Lecturer, Department of Biochemistry, Nobel Medical College, Biratnagar. E-mail:- shrawan yadav 36@yahoo.co.in 